\title{
Evaluation of FMR1 gene mutations in Turkish women newly diagnosed with primary ovarian failure
}

\author{
Esma Sarıkaya ${ }^{1}$, Aytekin Tokmak ${ }^{1 *}$, Esra Şükran Çakar², Gürhan Güney ${ }^{1}$, \\ Neslihan Düzkale², Müzeyyen Gülnur Özakşit ${ }^{1}$
}

\begin{abstract}
${ }^{1}$ Department of Obstetrics and Gynecology, ${ }^{2}$ Department of Medical Genetics, Zekai Tahir Burak Women's Health Research and Education Hospital, Ankara, Turkey
\end{abstract}

Received: 27 October 2018

Accepted: 28 November 2018

\section{*Correspondence:}

Dr. Aytekin Tokmak,

E-mail: aytekintokmak@gmail.com

Copyright: (c) the author(s), publisher and licensee Medip Academy. This is an open-access article distributed under the terms of the Creative Commons Attribution Non-Commercial License, which permits unrestricted non-commercial use, distribution, and reproduction in any medium, provided the original work is properly cited.

\begin{abstract}
Background: One of the known causes of ovarian dysfunction is fragile $\mathrm{X}$ mental retardation gene 1 (FMR1) premutation. The prevalence of FMR1 premutation in primary ovarian failure (POF) cases may differ between the studies due to some reasons including POF definition, definition of premutation, and determination of study population, ethnicity, genetic and environmental factors. In this study authors aimed to determine the prevalence of FMR1 mutations in patients who applied to present clinic and diagnosed as POF.

Methods: This retrospective cohort study was conducted on 200 women who had been newly diagnosed with POF in present clinic between 2013 and 2014. The presence of cytogenetic fragility was firstly investigated in all patients by using the lymphocyte culture method, and molecular analysis of the FMR1 gene was then performed. Genomic DNA's of cases were isolated using standard protocols, followed by polymerase chain reaction amplification with an appropriate program. Fragment analysis of the amplification products were performed by agarose gel electrophoresis. Results: Cytogenetic analysis results in 200 cases were numerically and structurally normal in all patients, and as a result of molecular genetic analysis of FMR1 gene; $1(0.5 \%)$ patient had complete mutation and $9(4.5 \%)$ patients had premutation carriage.

Conclusions: FMR1 gene mutations are common in women with POF. These mutations should be investigated in all patients presenting with POF, particularly in cases with early onset and family history of POF, and also genetic counseling should be given to those patients.
\end{abstract}

Keywords: Fragile X syndrome, Premature ovarian insufficiency, Premutation, Prevalence

\section{INTRODUCTION}

Primary or premature ovarian (POF) failure is defined as the development of hypergonadotropic hypogonadism in women under the 40 years of age. ${ }^{1}$ Smoking, low body mass index and family history were suggested as risk factors for POF. ${ }^{2}$ Although the exact cause of POF is unknown in the vast majority of cases, it is thought that genetic factors play an important role in the development of the disease. ${ }^{3}$ Such genetic defects including numerical chromosomal abnormalities, just like in the Turner syndrome, or different structural rearrangements, have been frequently correlated well with the deterioration of the ovarian function. ${ }^{3,4}$ The most frequent monogenetic cause of POF is premutation of the fragile $\mathrm{X}$ mental retardation gene 1 (FMR1) located at Xq27.3 in about $0.8-13 \%$ of women with POF. ${ }^{5}$

FMR1 gene product, the fragile $\mathrm{X}$ mental retardation protein (FMRP) is an RNA binding protein expressed in 
brain, testis and ovary, and works as a shuttle between various intracellular compartments that suppress and regulates translation of cellular messages. ${ }^{5}$

The CGG trinucleotide repeat in the 5' untranslated location of FMR1 is unstable. Persons with 55-199 repeats (termed 'premutation') are at risk of a late-onset tremor/ataxia disorder and, for women, are at risk for fragile X-associated POF (FXPOF). Fragile X premutation is common in the general population (prevalence in female neonate's ranges between 1/130 259 ), and about $20 \%$ of female carriers have FXPOF. ${ }^{6}$ So many satisfying arguments have demonstrated association among different FMR1 genotypes and changed ovarian function and damage to fertility. ${ }^{7}$ In addition, the prevalence of FMR1 gene mutations reported in POF ranges from 2 to $14 \%{ }^{8}$

Detection of the premutation is very important because these mutations transit to the next generations with anticipation and may cause premature menopause. By using the pedigree analysis, high risk women may be recommended to freeze their oocytes to have a child in future. To delay the menopausal symptoms, smoking should be reduced as much as possible and oral contraceptive drugs may be prescribed early.

CGG repeat numbers in the FMR1 gene have significant differences among ethnicities. In this study, authors aimed to investigate the prevalence of the FMR1 gene mutation in a Turkish population with early menopausal cases referred to present tertiary hospital in capital city of Turkey.

\section{METHODS}

This study was performed with peripheral venous blood samples taken from 200 women who had been diagnosed as POF in present clinic between January 2013 and December 2014. Institutional reviews board of the Zekai Tahir Burak Women's Health Education and Research Hospital approved the study.

An informed consent was not obtained due to the study design in the form of a retrospective medical record review. Authors analyzed the FMR 1 premutation of 200 women diagnosed as having POF from January 1, 2013 to 31 December 2014 at the Medical Genetics Department of the current hospital. All of the patients referred to present center had secondary amenorrhea for more than 6 months before the age of 40 years, and they also had serum follicle stimulating hormone levels higher than 40 IU/L on two measurements at least 1 month apart.

\section{Inclusion criteria}

The inclusion criteria for this cohort were as follows, no history of pelvic surgery, no exposure to chemotherapy or radiotherapy that could lead to ovarian dysfunction or failure, and a normal female 46, XX karyotype.
The presence of cytogenetic fragility was firstly investigated in patients whose initial-diagnosis is fragile $\mathrm{X}$, by using the lymphocyte culture method. Molecular analysis of the FMR1 gene was then performed in the patients. Commercially available Fragile X kits (Abbott Laboratories, Chicago, IL, USA) were used for molecular analysis. Genomic DNAs of cases were isolated using standard protocols, followed by PCR amplification with the appropriate program. Fragment analysis of the amplification products were performed by agarose gel electrophoresis. CGG repeat numbers; 54 and less were defined as normal, 55 to 200 cases were found as premutation carriers, and those over 200 were defined as fully mutated individuals.

\section{Statistical analysis}

Statistical Package for the Social Sciences (SPSS), version 22.0 (SPSS Inc., Chicago, IL, USA) was used for statistical analysis. Descriptive data and frequency calculated with the help of a computer. Continuous data were expressed as mean \pm standard deviation and median (minimum-maximum). Categorical variables were presented as number (percentage).

\section{RESULTS}

A total of 200 women with idiopathic POF were analysed during the study period and their medical records were reviewed retrospectively. The mean age of patients without FMR1 gene premutation/mutation (n:191) was $33.9 \pm 4.6(22-39)$ years. Fifty $(26.2 \%)$ cases were at the age of 30 years or less at the time of diagnosis. Of them, $71(37.2 \%)$ patients were smoker, and $62(32.5 \%)$ patients had family history for premature menopause.

Cytogenetic analysis results were numerically and structurally normal in all patients, and as a result of molecular genetic analysis of FMR1 gene; 1 (0.5\%) patient had complete mutation and $9(4.5 \%)$ patients had premutation carriage. All premutations were below 90 trinucleotide repeats. The fully mutated woman authors detected did not exhibit any physical sign of fragile $\mathrm{X}$ syndrome. The mean age of the 9 patients with premutation or mutation in Fragile X gene was $24.2+5.2$ (16-34) years. None of them were smoker. Eight (88.9\%) patients were under the age of 30, and six (66.7\%) patients had family history for either POF or mental retardation.

\section{DISCUSSION}

One of the known causes of ovarian dysfunction is FMR1 premutation. ${ }^{9}$ In spite of the causeless relationship between POF and FMR1 premutation has been described several times by several authors who emphasize the importance of preventing the formation of fragile $\mathrm{X}$ syndrome in these women or in their female relatives, underlying molecular mechanism is still unclear. ${ }^{4,8,10}$ The prevalence of FMR1 premutation in POF cases may 
differ between the studies due to some reasons including POF definition, definition of premutation, determination of study population, ethnicity, genetic and environmental factors.
Table 1 shows the prevalence of FMR1 premutation detected in POF patients from studies performed in different countries. ${ }^{3,4,7-26}$

Table 1: Prevalence of FMR1 gene premutations in women with POF among different countries.

\begin{tabular}{|c|c|c|c|}
\hline Author & Ethnicity & $\begin{array}{l}\text { The prevalence of POF in } \\
\text { patients with FMR1 premutation }\end{array}$ & $\begin{array}{l}\text { The prevalence of FMR1 } \\
\text { premutation in POF patients }\end{array}$ \\
\hline Kenneson et al ${ }^{11}$ & USA & & $0 / 33$ POF $(0 \%)$ \\
\hline \multirow{3}{*}{ Conway et al ${ }^{12}$} & \multirow{3}{*}{ UK } & & $6 / 129$ POF $(4.6 \%)$ \\
\hline & & & $-3 / 23$ familial $(13 \%)$ \\
\hline & & & $-3 / 106$ sporadic $(3 \%)$ \\
\hline \multirow{3}{*}{ Murray et $\mathrm{al}^{9}$} & \multirow{3}{*}{ UK } & & $6 / 147$ POF $(4.08 \%)$ \\
\hline & & & $-4 / 25$ familial $(16.6 \%)$ \\
\hline & & & $-2 / 122$ sporadic $(1.6 \%)$ \\
\hline Uzielli et al $^{13}$ & Italy & $13-25 \%$ & $7 / 108$ POF $(6.5 \%)$ \\
\hline Sherman et $\mathrm{al}^{8}$ & USA (Review) & $21 \%$ & $(2-14 \%)$ \\
\hline \multirow{3}{*}{ Marozzi et al ${ }^{14}$} & \multirow{3}{*}{ Italy } & & $6 / 106$ POF $(5.6 \%)$ \\
\hline & & & $-4 / 33$ familial $(12.1 \%)$ \\
\hline & & & $-2 / 61$ sporadic $(3.2 \%)$ \\
\hline Mallolas et $\mathrm{al}^{10}$ & Spain & $12.2 \%$ & $2 / 43$ POF $(4.6 \%)$ \\
\hline Gersak et $\mathrm{al}^{15}$ & Slovenia & & $4 / 83 \mathrm{POF}(4.8 \%)$ \\
\hline Hur et al & Korea & & $3 / 83$ POF $(3.6 \%)$ \\
\hline \multirow{3}{*}{ Bussani et $\mathrm{al}^{4}$} & \multirow{3}{*}{ Italy } & & $3 / 45$ POF $(6.6 \%)$ \\
\hline & & & $-0 / 5$ familial $(0 \%)$ \\
\hline & & & $-3 / 40$ sporadic $(7.5 \%)$ \\
\hline Lo et $\mathrm{al}^{17}$ & China & & 9/116 POF $(0.86 \%)$ \\
\hline Bodega et al ${ }^{18}$ & Italy & & 19/190 POF (10\%) \\
\hline Cronister et $\mathrm{al}^{19}$ & USA & & 1/10 POF (10\%) \\
\hline \multirow{2}{*}{ Bachelot et $\mathrm{al}^{20}$} & \multirow{2}{*}{ France } & & 8/197 POF (4.06\%) \\
\hline & & & -0 in familial $(0 \%)$ \\
\hline Ceylaner et $\mathrm{al}^{3}$ & Turkey & & 2/75 POF $(2.6 \%)$ \\
\hline Rajkiewicz et al ${ }^{21}$ & Poland & & $3 / 38$ POF $(7.9 \%)$ \\
\hline Ishizuka et $\mathrm{al}^{22}$ & Japan & & $2 / 128 \mathrm{POF}(0.7 \%)$ \\
\hline Ferrarini et $\mathrm{al}^{23}$ & Italy & & $(8 \%)$ \\
\hline Murray $^{24}$ & UK & & 254 POF $(2 \%)$ \\
\hline $\mathrm{Guo}^{25}$ & Han Chinese & & $2 / 379$ POF $(0.5 \%)$ \\
\hline Bouali et $\mathrm{al}^{26}$ & Tunusia & & $5 / 100$ POF $(5 \%)$ \\
\hline Lu et $\mathrm{al}^{7}$ & Han Chinese & & $1 / 122$ POF $(0.8 \%)$ \\
\hline
\end{tabular}

There are new findings that POF prevalence increases with increasing repeat size. It is also claimed that there may be a correlation between the number of repetitions and ovarian failure in POF patients with normal number of repeats, even if they are not in gray zone $(<45$ repeats). ${ }^{7}$

On the other hand, POF prevalence in premutation carriers which is originated from mother is similar to general population, suggesting that POF penetration of female individuals carrying FMR1 premutation is low. So the authors say that premutations inherited from the father lead to Fragile $\mathrm{X}$ syndrome more likely than the mother. $^{27}$ To explain this relation researchers hypothesized that there may be imprinting effect on the paternally inherited FMR1 premutations. ${ }^{4}$ In normal people the number of repeats is less than 55, amplification of the CGG trinucleotide repeats in the carriers of premutation is between 55 and 200 and no phenotypical effect is seen in FMR1 premutation. Amplification greater than 200 is accepted as full mutation and called fragile $\mathrm{X}$ syndrome. ${ }^{28}$

To screen the individuals who have POF in terms of fragile $\mathrm{X}$ is more advantageous than screening the mentally retarded individuals for fragile $\mathrm{X}$ because much more families are detected with this way that has these mutations. To the best of our knowledge, till we 
understand the role of FMR1 premutation, the FMR1 DNA test should be included to evaluate all sporadic or familial POF patients.

When authors investigate the literature, authors saw some researches about the relation between POF and FMR1 mutations. One of them is Conway et al study in United Kingdom (UK) in 1998. ${ }^{12}$ They found the prevalence of FMR1 premutations as $4.6 \%$ in 129 number of POF patients. The premutation seen in $3(3 \%)$ of the 106 sporadic cases, while the premutation were detected in 3 (13\%) out of 23 cases who have history of familial POF. In a similar study conducted in 1998 in the UK, Murray and colleagues found the fragile $\mathrm{X}$ premutation ratio $(4.08 \%)$ in POF patients similar to the previous Conway et al's study. ${ }^{29}$ Uzielli et al, from Italy in 1999 found the prevalence of POF in FMR1 premutation carriers as between $13 \%-25 \%$ and the prevalence of FMR1 permutations in POF patients as $6.5 \%$ among 108 patients. ${ }^{13}$ Gersak et al from Slovenia in 2003 studied the prevalence of FMR1 premutation in POF patients and found it as $4.8 \%$ among 83 patients. ${ }^{15}$

In a review from USA, among the carriers of the FMR1 premutation patients, Sherman noted the prevalence of POF as $21 \%$ and in FMR1 premutation carriers whereas the prevalence of FMR1 premutation in POF patients was noted as between 2\%-14\%. ${ }^{8}$ In Brazil, Machado-Ferreira Mdo et al, found the prevalence of POF in FMR1 premutation carriers as high as $33 \% .{ }^{30}$ In 2005 Lo et al, from Chinese searched the prevalence of FMR1 premutation among 116 POF patients and found the ratio as low as $0.86 \% .{ }^{17}$ The following studies from China found similar results. ${ }^{7,25}$ The reason why mutation rate is so low in Chinese POF patients is unknown but may be due to genetic and environmental factors such as frequent use of herbal medicine. A previous study from present hospital found that the FMR1 premutation among the 75 POF patients was $2.7 \% .^{3}$ In present study authors analyzed molecular genetic analysis of FMR1 gene in 200 POF diagnosed patients. Authors found the prevalence of premutation carriage ratio as $4.5 \%$. The ratios authors have achieved as a result of this study are similar to those of other studies conducted in other parts of worldwide, except data from far-eastern regions.

According to present data, until the exact role of FMR1 mutation is not understood, authors strongly recommended FMR1 DNA testing to sporadic or familial ovarian failure patients to identify premutation carriers who have the risk of expansion and anticipation. Patients with such risks may be advised to freeze their oocytes, if they are planning to have children or stop smoking before facing with premature menopause that may develop in future.

\section{Funding: No funding sources Conflict of interest: None declared Ethical approval: Not required}

\section{REFERENCES}

1. ESHRE Guideline Group on POI, Webber L, Davies M, Anderson R, Bartlett J, Braat D, Cartwright B, et al. ESHRE Guideline: management of women with premature ovarian insufficiency. Human Reprod. 2016;31(5):926-37.

2. Tokmak A, Yıldırım G, Sarıkaya E, Çınar M, Boğdaycioğlu N, Yılmaz FM, et al. Increased oxidative stress markers may be a promising indicator of risk for primary ovarian insufficiency: a cross-sectional case control study. Brazil J Gynecol Obstet. 2015;37(9):411-6.

3. Ceylaner G, Altinkaya SO, Mollamahmutoglu L, Ceylaner S. Genetic abnormalities in Turkish women with premature ovarian failure. Int J Gynaecol Obstet. 2010;110:122-4.

4. Bussani C, Papi L, Sestini R, Baldinotti F, Bucciantini S, Bruni V, et al. Premature ovarian failure and fragile $\mathrm{X}$ premutation: a study on 45 women. Eur J Obstet Gynecol Reprod Biol. 2004;112(2):189-91.

5. Wittenberger MD, Hagerman RJ, Sherman SL, McConkie-Rosell A, Welt CK, Rebar RW, et al. The FMR1 premutation and reproduction. Fertil Steril. 2007;87(3):456-65.

6. Saldarriaga W, Lein P, González Teshima LY, Isaza C, Rosa L, Polyak A, et al. Phenobarbital use and neurological problems in FMR1 premutation carriers. Neurotoxicol. 2016;53:141-7.

7. Lu CL, Li R, Chen XN, Xu YY, Yan LY, Yan J, et al. The 'normal' range of FMR1 triple CGG repeats may be associated with primary ovarian insufficiency in China. Reprod Biomed Online. 2017;34:175-80.

8. Sherman SL. Premature ovarian failure in the fragile X syndrome. Am J Med Genet. 2000;97(3):189-94.

9. Murray A, Webb J, Grimley S, Conway G, Jacobs P. Studies of FRAXA and FRAXE in women with premature ovarian failure. J Med Genet. 1998;35(8):637-40.

10. Mallolas J, Duran M, Sanchez A, Jimenez D, Castellvi- Bel S, Rife $M$ et al. Implication of the FMR1 gene in menopause: study of 147 Spanish women. Menopause. 2001;8:1006-110.

11. Kenneson A, Cramer DW, Warren ST. Fragile X premutations are not a major cause of early menopause. Am J Hum Genet. 1997;61(6):1362-9.

12. Conway GS, Payne NN, Webb J, Murray A, Jacobs $\mathrm{PA}$. Fragile $\mathrm{X}$ premutation screening in women with premature ovarian failure. Hum Reprod. 1998;13:1184-7.

13. Uzielli ML, Guarducci S, Lapi E, Cecconi A, Ricci U, Ricotti G, et al. Premature ovarian failure (POF) and fragile $\mathrm{X}$ premutation females: from POF to to fragile $\mathrm{X}$ carrier identification, from fragile $\mathrm{X}$ carrier diagnosis to POF association data. Am J Med Genet. 1999;84:300-3.

14. Marozzi A, Vegetti W, Manfredini E, Tibiletti MG, Testa G, Crosignani PG, et al. Association between 
idiopathic premature ovarian failure and fragile $\mathrm{X}$ premutation. Hum Reprod. 2000;15(1):197-202.

15. Gersak K, Meden-Vrtovec H, Peterlin B. Fragile X premutation in women with sporadic premature ovarian failure in Slovenia. Hum Reprod. 2003;18:1637-40.

16. Hur CY, Choi YM, Park SH, Yoon BK, Lee KS, Na $\mathrm{YJ}$, et al. Fragile $\mathrm{X}$ Premutation in Patients with Idiopathic Premature Ovarian Failure. Korean J Obstet Gynecol. 2003;46:978-83.

17. Lo TK, Lo IF, Chan WK, Tong TM, Lam ST, Chromosomal abnormalities and FMR1 gene premutation in Chinese women with premature menopause Hong Kong Med J. 2005;11:243-50.

18. Bodega B, Bione S, Dalprà L, Toniolo D, Ornaghi F, Vegetti $\mathrm{W}$, et al. Influence of intermediate and uninterrupted FMR1 CGG expansions in premature ovarian failure manifestation. Hum Reprod. 2006;21:952-7.

19. Cronister A, Teicher J, Rohlfs EM, Donnenfeld A, Hallam S. Prevalence and instability of fragile $X$ alleles: implications for offering fragile $X$ prenatal diagnosis. Obstet Gynecol. 2008;111:596-601.

20. Bachelot A, Rouxel A, Massin N, Dulon J, Courtillot C, Matuchansky C, et al. POF-GIS Study Group. Phenotyping and genetic studies of 357 consecutive patients presenting with premature ovarian failure. Eur J Endocrinol. 2009;161:179-87.

21. Rajkiewicz M, Szlendak-Sauer K, Sulek A, GawlikZawislak S, Krysa W, Radowicki S, et al. A molecular and cytogenetic investigation of FMR1 gene premutations in Polish patients with primary ovarian insufficiency. Eur J Obstet Gynecol Reprod Biol. 2011;155:176-9.

22. Ishizuka B, Okamoto N, Hamada N, Sugishita Y, Saito J, Takahashi N, et al. Number of CGG repeats in the FMR1 gene of Japanese patients with primary ovarian insufficiency. Fertil Steril. 2011;96:1170-4.

23. Ferrarini E, Russo L, Fruzzetti F, Agretti P, De Marco G, Dimida A, et al. Clinical characteristics and genetic analysis in women with premature ovarian insufficiency. Maturitas. 2013;74:61-7.
24. Murray A, Schoemaker MJ, Bennett CE, Ennis S, Macpherson JN, Jones M, et al. Population-based estimates of the prevalence of FMR1 expansion mutations in women with early menopause and primary ovarian insufficiency. Genet Med. 2014;16:19-24.

25. Guo T, Qin Y, Jiao X, Li G, Simpson JL, Chen ZJ. FMR1 premutation is an uncommon explanation for premature ovarian failure in Han Chinese. PloS One. 2014;9(7):e103316.

26. Bouali N, Hmida D, Mougou S, Bouligand J, Lakhal B, Dimessi S, et al. Analysis of FMR1 gene premutation and $\mathrm{X}$ chromosome cytogenetic abnormalities in 100 Tunisian patients presenting premature ovarian failure. Ann Endocrinol (Paris). 2015;76:671-8.

27. Hundscheid RD, Sistermans EA, Thomas CM, Braat DD, Straatman H, Kiemeney LA, et al. Imprinting effect in premature ovarian failure confined to paternally inherited fragile $\mathrm{X}$ premutations. Am $\mathrm{J}$ Hum Genet. 2000;66(2):413-8.

28. Corrigan EC, Raygada MJ, Vanderhoof VH, Nelson LM. A woman with spontaneous premature ovarian failure gives birth to a child with fragile $\mathrm{X}$ syndrome. Fertil Steril. 2005;84(5):1508-e5.

29. Murray A, Webb J, Grimley S, Conway G, Jacobs P. Studies of FRAXA and FRAXE in women with premature ovarian failure. J Med Genet. 1998;35:637-40.

30. Machado-Ferreira MD, Costa-Lima MA, Boy RT, Esteves GS, Pimentel MM. Premature ovarian failure and FRAXA premutation: Positive correlation in a Brazilian survey. Am J Med Genet Part A. 2004;126(3):237-40.

Cite this article as: Sarıkaya E, Tokmak A, Çakar ES, Güney G, Düzkale N, Özakşi MG. Evaluation of FMR1 gene mutations in Turkish women newly diagnosed with primary ovarian failure. Int J Reprod Contracept Obstet Gynecol 2019;8:420-4. 